\title{
Attitudes Towards Utilising Mobile Banking Applications Among Generation Z Consumers in South Africa
}

Moshele Koenaite 1,

Eugine Tafadzwa Maziriri 2*,

Tinashe Chuchu ${ }^{3}$

1 Marketing Division, School of Business Sciences, Faculty of Commerce, Law and Management, University of the Witwatersrand, Johannesburg, South Africa

2 Department of Business Management, Faculty of Economic and Management Sciences, University of the Free State, Bloemfontein, South Africa.

3 Marketing Division, School of Business Sciences, Faculty of Commerce, Law and Management, University of the Witwatersrand, Johannesburg, South Africa

\begin{tabular}{|c|c|}
\hline ARTICLE INFO & ABSTRACT \\
\hline $\begin{array}{l}\text { ISSN: 2723-1097 } \\
\text { Keywords: } \\
\text { Knowledge of mobile } \\
\text { banking applications; } \\
\text { Perceived usefulness of } \\
\text { mobile banking } \\
\text { applications; attitudes } \\
\text { towards mobile } \\
\text { banking applications; } \\
\text { actual use of mo-bile } \\
\text { banking applications }\end{array}$ & $\begin{array}{l}\text { In today's post-modern era, the banking industry is becoming a digital rather than } \\
\text { a physical system. Digital banking has been synonymous with the fourth industrial } \\
\text { revolution making a notable impact on the African continent. Therefore, the } \\
\text { purpose of this research is to empirically investigate consumer attitudes towards } \\
\text { mobile banking applications in South Africa. A positivist paradigm underpinned } \\
\text { the study, and a descriptive design was employed. To test the proposed hypotheses } \\
\text { a unique conceptual model was developed. Non-probability sampling was adopted } \\
\text { in selecting appropriate participants. Data was collected from } 325 \text { willing } \\
\text { participants through a survey. In terms of analysis, SPSS and AMOS were utilised } \\
\text { to generate descriptive statistics and hypotheses testing. The results established } \\
\text { that attitudes towards mobile banking applications and actual use of mobile } \\
\text { banking applications was the strongest relationship. The empirical evidence } \\
\text { presented in this study adds value to the existing research on mobile-banking } \\
\text { within the 4th industrial revolution, particularly in South Africa, a largely under- } \\
\text { researched area. }\end{array}$ \\
\hline
\end{tabular}

\section{Introduction}

Technology has revolutionised the way the modern economy functions and is set to do this at an exponential rate going into the so-called fourth industrial revolution (Coetzee, 2018). With the rise of globalisation, banks have been forced to launch new channels to gain a competitive advantage (Koenaite, Chuchu \& Venter de Villiers, $\underline{2019}$ ). In fact, they have been under significant pressure to reduce costs and further their financial positions through innovative products and services (Koenaite et al., 2019). As a result, most banks have adopted a multi-channel distribution approach,

Journal of Business and Management Review Vol. 2 No. 62021 Page 417-438

DOI: $10.47153 /$ jbmr26.1452021

*Corresponding Author

Email address: maziririet@ufs.ac.za 
which has given them a global presence with customers able to access banking services from across borders (Koenaite et al., 2019). Generation $Z$ is the demographic cohort which follows the Generation Y or Millennials and emerge typically from the mid-to late-1990s (Strauss \& Howe, 1991). This group is progressively replacing Generation Y and has become the consumers to watch with an increasing knowledge of technology and new innovations (Seemiller \& Grace, 2016). According to Duffett (2017) there are few empirical international inquiries that consider Generation $Z$. This study attempt to investigate this cohort in depth. The rapid development of Information Technology (IT) have brought remarkable growth across the world in mobile banking (m-banking) especially in the past few years (Shankar, Jebarajakirthy \& Ashaduzzaman, 2020). Luo, Li, Zhang and Shim (2010) describe $\mathrm{m}$-banking as an innovative method for accessing banking services via a channel whereby the customer interacts with a bank via a mobile device. The Internet has taken the banking industry to a remarkable and tremendous growth track (Khan \& Khan, 2012), paving way for research in m-banking applications. According to a forecast from Juniper Research, it is estimated that the number of mobile banking users will reach two billion worldwide by 2022 (Maynard, 2020). The usage of m-banking can also be attributed to the easy access to mobile devices, and the fact that internet has become cheaper and more acceptable (Ratten, 2011). The introduction of mobile banking offers even greater convenience to customers (Afshan \& Sharif, 2016), a recent approach to the provision of mobile banking services by retail banks is through mobile banking applications ('mobile banking apps') (Moser, 2015). The emergence of this new banking platform, i.e., mobile banking applications, have come about through developers having to innovate due to a global landscape of increased crime, fraud, technological advancement and pressure from banks to cut costs for both the consumer as well as for the business (Balabanoff, 2014). In addition, innovative bank marketers have been driven by consumers to constantly add value to their offerings (Balabanoff, 2014). The ease of banking, being a primary value add, has steered bankers to better options and mobile banking applications achieve this objective as the consumer is now able to perform a multitude of banking functions (Balabanoff, 2014). Bankers see this as another gateway for improving the bottom line, as consumer convenience creates increased transactions (Virgillito, 2013).

Despite the ability to provide essential insights into mobile banking and mobile banking applications, it is essential to note that there is still a shortage of studies that have examined attitudes towards utilising mobile banking applications among Generation $\mathrm{Z}$ consumers in South Africa. Consequently, further scholarly introspections are considered necessary. Much of what is written on the subject is based on samples from international countries such as Malaysia, India, Saudi Arabia, Jordan, Lebanon, Poland, Spain and the United States of America. For example, Rehman and Shaikh (2020) examined the critical factors influencing consumers' behavioural intention towards mobile banking in Malaysia. In addition, Shankar, and Kumari (2016) determined the factors affecting mobile banking adoption behaviour in India. Futhermore, Baabdullah, Alalwan, Rana, Kizgin, and Patil (2019) examined 
mobile banking (M-Banking) consumer use in Saudi Arabia. Alafeef, Singh and Ahmad, (2011) investigated the influence of demographic factors on the adoption level of mobile banking applications in Jordan. Audi (2015) studied the impact of mobile banking adaptation in Lebanon. Borowski-Beszta, and Kiermas (2019) examined the usage of mobile banking applications in Poland. Additionally, Munoz-Leiva, ClimentCliment and Liébana-Cabanillas, (2017) examined the determinants of intention to use mobile banking apps in Spain. Moreover, Vedadi and Warkentin (2016) determined the continuance intention on using mobile banking applications among 256 college students who were users of mobile banking applications of multiple banks in the United States of America.

Even in South Africa, previous academics have performed their research in different contexts. For example, Thusi and Maduku (2020) surveyed South African millennials, to determine the acceptance and use of retail mobile banking apps. In addition, Masinge, (2011) investigated the factors influencing the adoption of mobile banking services at the Bottom of the Pyramid in South Africa. Govender and Sihlali (2014) investigated the factors that influence the adoption of mobile banking (mbanking) services by students within the KwaZulu Natal Province of South Africa. Maduku (2014) also examined the behavioural intention towards mobile banking usage by South African retail banking clients. Van Deventer, De Klerk and Bevan-Dye (2017) investigated the influence of perceived integrity and perceived system quality on Generation Y students' perceived trust in mobile banking in South Africa. Moreover, in his study entitled, "Cell Phone Banking Adoption in South Africa", Shambare (2011) surveyed 124 cell phone users from Gauteng, Mpumalanga, and Limpopo provinces, to examine banking consumers' perceptions of cell phone banking attributes, and how these may affect adoption.

While these studies are informative, they did not examine the factors influencing attitudes towards and using mobile banking applications among consumers. Consumer attitudes are essential for any product to be successfully evaluated (Mashele \& Chuchu, 2018). Hence, this study explores mobile banking in the developing country context of South Africa. The study will continue the stream of literature among financial service marketing researchers on providing country-specific contextual knowledge on mobile banking applications in developing countries. Furthermore, the epicentre of this present study is Generation Z, where there is a shortage of empirical studies in mobile banking. This generation seems to be the biggest future marketing challenge, since it is the driver of innovation and change (Morgan, 2016; Wood, 2013). Therefore, this article helps to tackle the gap by using a sample of Generation Z student consumers from a context in a developing country.

Moreover, very few (if any) researchers have used structural Equation Modelling (SEM) to test the causal relationships between knowledge of mobile banking applications, perceived usefulness of mobile banking applications, attitudes towards mobile banking applications, actual use of mobile banking applications. In terms of this study, this robust research model is one of a kind. Thus, this research adds to the 
literature by taking results from a geographically distinct context by testing the suggested model in a developing country context.

The rest of the paper is organised as follows: To begin with, this examination is placed in context. Secondly, the theoretical framework underlying this study is shown, thus prompting research hypotheses development. Thirdly, the section on research design and methodology will follow. Finally, there is a presentation of the findings, discussion and conclusion.

\section{Literature Review}

\section{Mobile banking applications}

Mobile apps are downloaded and installed via an app store and can access system resources, such as GPS and the camera function. Mobile apps live and run on the device itself (Stevens, 2018). In addition, mobile banking apps streamline the mobile experience. For basic transactions, more and more customers are using mobile banking which is being rapidly pitched by banks offering mobile banking applications with user-friendly interfaces (Khrais, 2015). In addition, Nicoletti (2014) highlights how a mobile banking application is downloaded through a secure and authenticated mobile device process. Once downloaded, the mobile application provides an optimal user experience (Nicoletti, 2014). According to Basar, Alptekin, Volaka, Isbilen and Incel (2019), mobile banking applications are among the most sensitive apps for secure authentication. Customers tend to embrace services that offer convenience (Mgxaji, Chinomona \& Chuchu, 2016). This is why customers widely use mobile banking services due to ease of access and use. These applications must perform remote authentication using user credentials consisting of user-name and password (Basar, Alptekin, Volaka, Isbilen \& Incel, 2019).

Furthermore, the bank usually requires a confirmation password after the completion of a transaction as an additional security measure and the use of a confirmation password extends the processing time, which may cause difficulty in the application usage for users (Basar, et al., 2019). According to Abbortt (2015), all large banks in South Africa are provided smartphone applications and have become particularly popular in the urban areas. Precisely, Chigada and Hirschfelder (2017) mentioned that the five most popular banks in South Africa are ABSA, Capitec, First National Bank, Nedbank and Standard Bank. All provide mobile applications (Columinate, 2015).

\section{Rationale and Importance of Selecting Generation Z students}

Generation Z are young adults born in 1995 or later (Bassiouni \& Hackley, 2014; Fister-Gale, 2015) and are highly educated, technologically savvy, innovative and creative (Priporas, Stylos \& Fotiadis, 2017). It is the first generation born into a digital world that lives online and virtually integrates and engages with its favourite brands (Bernstein, 2015). Generation Z are heavy users of technology and they see it as an 
instrument for them (Van den Bergh \& Behrer, 2016). According to Karsh (2020), Generation $\mathrm{Z}$ has the highest awareness level in financial technology than older generations. Sachdev (2019) revealed in his study that the Generation Z cohort intensively depend on using technology in their lives. Vahrenkamp (2017) explained in his research (Raddon's Report) that Gen Z will expect the future of the mobile-based services for traditional financial institutions and shape their services. The funny fact is that this generation was born with a smartphone in hand (Karsh, 2020). It comes as no surprise that millennials and Gen $Z$ are the two groups using mobile banking apps the most (White, 2021). In addition, White (2021) discovered that 99\% of Gen Z and 98\% of millennials use a mobile banking app for a wide range of tasks, including viewing account balances, checking their credit score and depositing a check. Deducing from the aforementioned elucidations, banks have to take note and adapt to the shift in customer habits and expectations that the Generation $\mathrm{Z}$ cohort is bringing to remain relevant to this new breed of customers.

\section{Theoretical Grounding of the Study}

This study uses the Technology Acceptance Model (TAM) and the Theory of Planned Behaviour (TPB) as the theoretical grounding of this study. These theories are discussed in the subsequent sections.

\section{The Technology Acceptance Model (TAM)}

Davis initially proposed this model in 1989 and has grown to be a maximum extensively used model to explain user acceptance of new technologies (Matikiti, Mpinganjira, \& Roberts-Lombard, 2018). TAM was created from the Theory of Reasoned Action (Fishbein \& Ajzen 1975) and offers a foundation for tracking how internal factors affect new systems. TAM represents the fact that the real use of a fresh technology depends on the user's attitude towards the technology, the perceived ease of use of the technology, and the perceived advantages that can be derived from its use (see Figure 1). Accordingly, behaviour is anticipated using the two variables of perceived ease of use and perceived usefulness (Fishbein \& Ajzen, 1975). This model deduced that the person will be willing to embrace it whenever a person perceives that using a certain technology will help improve efficiency or deliver some advantages. The model has been shown to be accurate in describing acceptance behaviour in certain fields of information systems (Matikiti, Mpinganjira, \& Roberts-Lombard, 2018). Moreover, Yen and $\mathrm{Wu}(2016)$ also suggested that the TAM model has been utilised in information systems, marketing, and electronic commerce. This is therefore making it relevant to the present study.

\section{Theory of Planned Behavior (TPB)}

The Theory of Planned Behavior (TPB) was developed by Ajzen (1985) as an extension of Theory of Reasoned Action (TRA) by Fishbein and Ajzen, (1977) which is one of the most fundamental and influential theories of human behaviour (Venkatesh et al., 2003). This model has three variables to predict behavioural intentions, which 
include attitude toward a specific behaviour, subjective norms (others' perceptions or judgments to engage or not engage in the behaviour) and perceived behavioural control (perception of the ease or difficulty of performing the behaviour) (Ajzen, 1991).

The above determinants of TPB are helpful in predicting individual usage of many different technologies (Hung, Ku \& Chang, 2003). Nguyen (2015) further asserts that the TPB model is valued for considering the social influences in users' intention and behavior. This theory enables the researcher to predict behavioural intentions with a high degree of accuracy (Ajzen, 1991). The TPB model is concerning this study as it expresses more about behavioural intention and actual behaviour. This is in line with the purpose of this study as it tries to examine the attitudes and actual use of mobile banking applications.

\section{Theoretical Model and Hypotheses Development}

Premised on the literature on technology acceptance model (TAM) and this study conceptualises a research model provided in Figure 3. The theoretical model illustrates the suggested interconnection of four constructs: knowledge of mobile banking applications; perceived usefulness of mobile banking applications; attitudes towards mobile banking applications; actual use of mobile banking applications. The following sections will review the literature on the study's main variables. Moreover, the hypothesised connections between the study variables are discussed in the subsequent sections based on past studies and logically deriving from prior results.

Figure 1. Theoretical Model

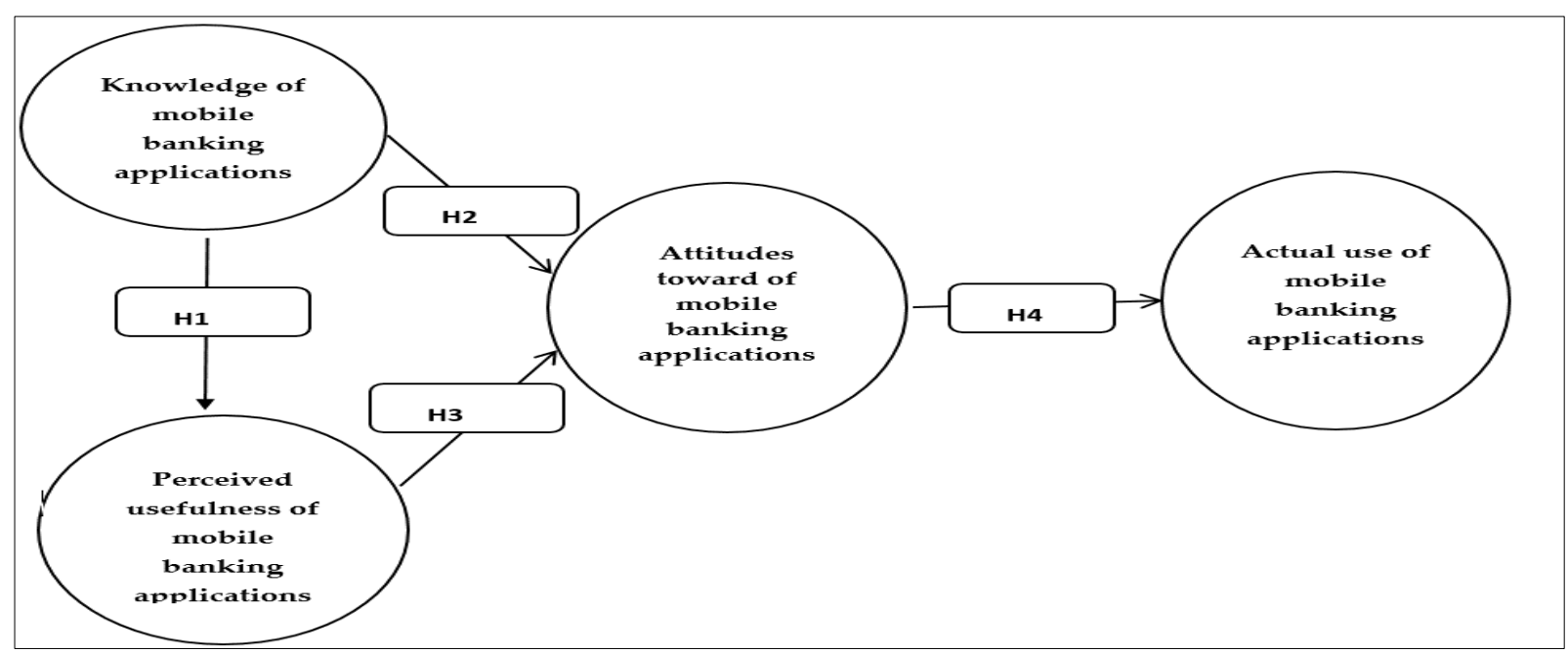

Source: author's own work

Knowledge of mobile banking applications and perceived usefulness of mobile banking applications

Perceived usefulness is one of the fundamental elements of the technology acceptance model as digital banking is concened (Wang, Wang, Wang, Wei \& Wang, 
2020). Therefore, this makes customers' knowledge of digital banking imperative for succesful adoption of digital banking. The amount of knowledge that customers have of digital banking directly influences those customers perception of its usefullness $(\underline{\mathrm{Gu}}$ et al., 2009). Additionally, $\mathrm{Wu}$, Lin, Li, \& Lin (2010) postulated that knowledge and support directly and positively lead to online banking's perceived usefulness. Eriksson, Kerem and Nilsson (2005) established that perceived usefulness has a robust influence over the customer's usage of internet banking services. Successfulness knowledge management of banking process is dependent on perceived usefulness of the banking processes (Bals, Smolnik \& Riempp, 2007). Based on the above-mentioned evidence the following hypothesis is postulated.

H1: There is a positive relationship between knowledge of mobile banking applications and perceived usefulness of mobile banking applications

\section{Knowledge of mobile banking applications and attitudes toward mobile banking applications}

The extent to which customers are knowledgeable of digital banking directly influences those attitudes toward digital banking (Gu, Lee \& Suh, 2009). In addition,

$\mathrm{Wu}$, Lin, Li, \& Lin (2010) suggested that knowledge and support directly and positively make customer attitudes toward online banking positive. Shaikh et al. (2015) customers' knowledge of digital banking is generally associated with favourable attitudes toward digital banking. Based on the above-mentioned empirical support, the following hypothesis was proposed:

H2: There is a positive relationship between knowledge of knowledge of mobile banking applications and mobile banking application

Perceived usefulness of mobile banking applications and attitudes towards mobile banking applications

Perceived usefulness of digital banking is directly and positively related to attitudes towards accepting digital banking (Lin, 2011). Purnawirawan, De Pelsmacker and Dens (2012) postulate that perceived usefulness affects consumer attitudes and intention to use online services. In addition, Shaikh, Glavee-Geo and Karjaluoto (2015) also suggested that the ease of using mobile is directly and positively liked to attitudes towards digital banking. According to Rose and Fogarty (2006) perceived usefulness of self-service banking directly influences consumer attitudes toward the services. Therefore, inferring from the literature and the empirical evidence above-mentioned, the study postulates that:

H3: There is a positive relationship between perceived perceived usefulness of mobile banking applications and attitudes towards mobile banking applications

Attitudes towards mobile banking applications and actual use of mobile banking applications 
Within the IT literature, TAM has been widely applied to understand the attitude one holds about the use of technology, which is used to predict the adoption and use of technology. The attitude construct in TAM represents the attitude toward the behaviour of using technology. An individual's attitude is a significant factor that affects one's behaviour in accepting or rejecting technology. Attitude involves judgment whether the behaviour is good or bad and whether the user is in favour or against performing it, (Leonard et al., 2004). TAM suggests that a prospective user's overall feelings or attitude towards using a given technology-based system represent major determinants as to whether or not he/she will ultimately use the system (Davis 1993). Therefore, inferring from the literature and the empirical evidence abovementioned, the study postulates that:

H4: There is a positive relationship between attitudes towards mobile banking applications and actual use of mobile banking applications

\section{Method}

From the ontological perspective of objectivism of the research, this investigation pursues a positivistic framework as it seeks to discover a link between the variables presented for this analysis and uses measurement instruments for gathering data. Hence, a quantitative approach has been applied as it improves accuracy of findings using statistical analysis. The design was suitable to solicit the required information relating to knowledge of mobile banking applications, perceived usefulness of mobile banking applications, attitudes toward mobile banking applications and actual use of mobile banking applications. In addition, the approach enables one to examine the causal relationships with the constructs used in the study. Being quantitative in nature, the measurement instrument was compiled from several existing scales that were adapted to suit the purpose of the study. Once scale reliability and validity were established, structural equation modelling (SEM) was used to test the model fit, followed by the hypotheses testing and path modelling. Structural equation modelling was performed using AMOS 26 software, and the descriptive statistics were obtained through SPSS 26 software.

\section{Sample and Data Collection}

This research was performed among Generation $Z$ students from the University of the Witwatersrand in Braamfontein, Johannesburg, within the Gauteng province of South Africa. This research used Generation Z students as the sample, as this generation is considered to be the most technically knowledgeable population group and college students are recognised as the new technology's early adopters (Hwang, 2017). At the moment of data collection, the students included in the sample had to be active, registered students. A primary identifier of this criterion was the student card holding the name and year of enrolment of each student. With respect to the sampling frame, a list of registered students has been used as a sampling frame in the university database. This study therefore used a simple random sampling technique because each 
element of the population had an equal and known chance of being selected as part of the sample (Weideman, 2014); for example, where each name in the list of students registered in the database of the university had an equal chance of being selected. The questionnaires made it clear that the respondents ' anonymity would be assured and that the research was for educational purposes only. The sample size Raosoft calculator was used to calculate the sample size (Raosoft Inc., 2004). The calculation considered the total student population enrolment of approximately 40259 , a 5 percent margin of error, 95 percent interval of confidence, and the recommended 50 percent distribution, and returned a minimum sample size of 208 respondents. Of the 377 questionnaires distributed, 325 questionnaires returned were usable, resulting in a response rate of $86.2 \%$.

\section{Ethical Considerations}

Permission was obtained from the administration of the University of the Witwatersrand. The researchers acquired the letter of permission, which allowed him to collect information from the Generation $Z$ students. The approval of ethical clearance was sincerely affirmed, and this study was conducted in compliance with the ethical standards of scholastic science, including, in addition to other issues, the protection of participants' identities and the assurance of the confidentiality of collected data obtained from the participants. It is imperative to note that, an ethical clearance certificate (protocol number: CBUSE/1197) to conduct the study was obtained from the University of the Witwatersrand Research Ethics Committee.

\section{Result and Discussion}

The gathered data were recorded on a Microsoft Excel spreadsheet after screening returned questionnaires. The data were analysed using software for descriptive statistics, Cronbach's alpha values and correlations, and the Statistical Package for Social Sciences (SPSS version 26.0). To test the psychometric properties of the measurement scales and hypotheses, the Analysis of Moment Structures (AMOS version 26.0) statistical software was utilised.

\section{Measurement instrument and questionnaire design}

The variables under investigation were operationalised from previous studies. Modifications to the scales were made to reflect the study context of mobile banking applications. The measurement scales, items used, sources, and Cronbach's alpha values for the scales are indicated in Table 1 . The scale indicators were affixed to a strongly disagree (1) to strongly agree (5) Likert-scale continuum.

Table 1. The Research Instrument 


\begin{tabular}{|c|c|c|}
\hline $\begin{array}{l}\text { Variable and } \\
\text { Source }\end{array}$ & Scale items & $\begin{array}{l}\text { Cronbach's } \\
\text { Alpha }\end{array}$ \\
\hline $\begin{array}{l}\text { Knowledge of } \\
\text { mobile banking } \\
\text { applications: } \\
\text { As adapted } \\
\text { from Lee } \\
(2016) .\end{array}$ & $\begin{array}{l}\text { - I consider myself as knowledgeable about } \\
\text { mobile banking applications } \\
\text { - I usually I talk a lot about mobile banking } \\
\text { applications } \\
\text { - I know about mobile banking applications } \\
\text { more than people around me do. } \\
\text { - I usually think a lot more about mobile } \\
\text { banking applications } \\
\text { - I feel knowledgeable about mobile banking } \\
\text { applications in general. } \\
\text { - I feel confident about my ability to use mobile } \\
\text { banking applications }\end{array}$ & 0.870 \\
\hline $\begin{array}{l}\text { Perceived } \\
\text { usefulness of } \\
\text { mobile banking } \\
\text { applications: } \\
\text { As adapted } \\
\text { from } \\
\frac{\text { Mohammadi, }}{(2015) .}\end{array}$ & $\begin{array}{l}\text { - Using mobile banking applications would } \\
\text { enable me to pay more quickly } \\
\text { - Using mobile banking applications makes it } \\
\text { easier for me to conduct transactions } \\
\text { - I would find mobile banking applications a } \\
\text { useful possibly for conducting transactions. } \\
\text { - Mobile banking applications appears to be } \\
\text { practical }\end{array}$ & 0.901 \\
\hline $\begin{array}{l}\text { Attitude } \\
\text { towards mobile } \\
\text { banking } \\
\text { applications: } \\
\text { As adapted } \\
\text { from } \underline{\text { Nel, }} \\
\text { Raleting \& } \\
\text { Boshoff }(2012)\end{array}$ & $\begin{array}{l}\text { - In my opinion, it is desirable to use mobile } \\
\text { banking applications } \\
\text { - I think it will be good for me to use mobile } \\
\text { banking applications } \\
\text { - Overall, my attitude toward mobile banking } \\
\text { applications is favourable } \\
\text { - I think using mobile banking applications is a } \\
\text { good idea } \\
\text { - Generally speaking, I like the idea of mobile } \\
\text { banking applications }\end{array}$ & 0.945 \\
\hline $\begin{array}{l}\text { Actual use of } \\
\text { mobile banking } \\
\text { applications: } \\
\text { As adapted } \\
\text { from } \\
\frac{\text { Mohammadi, }}{\underline{(2015)} .}\end{array}$ & $\begin{array}{l}\text { - I use/would consider using mobile banking } \\
\text { applications } \\
\text { - I feel positive about using a mobile banking } \\
\text { application and expect to continue feeling } \\
\text { this way. } \\
\text { - I expect a mobile banking application to } \\
\text { become my main/only way of banking. } \\
\text { - I would use a mobile banking application } \\
\text { over using physical channels (branches, } \\
\text { ATMs). }\end{array}$ & 0.913 \\
\hline
\end{tabular}




\begin{tabular}{lccc}
\hline $\begin{array}{l}\text { Variable and } \\
\text { Source }\end{array}$ & Scale items & $\begin{array}{c}\text { Cronbach's } \\
\text { Alpha }\end{array}$ \\
\hline & $\begin{array}{l}\text { I would recommend the use of mobile } \\
\text { banking applications to my friends and } \\
\text { family. }\end{array}$ & \\
\hline
\end{tabular}

\section{Psychometric Properties of Measurement Scales}

The assessment of the measurement scales" psychometric characteristics was performed through a CFA to determine the construct's reliability, validity and model fit. Table 3 shows the outcomes of the CFA assessment.

Table 2. Psychometric Properties of Measurement Scales.

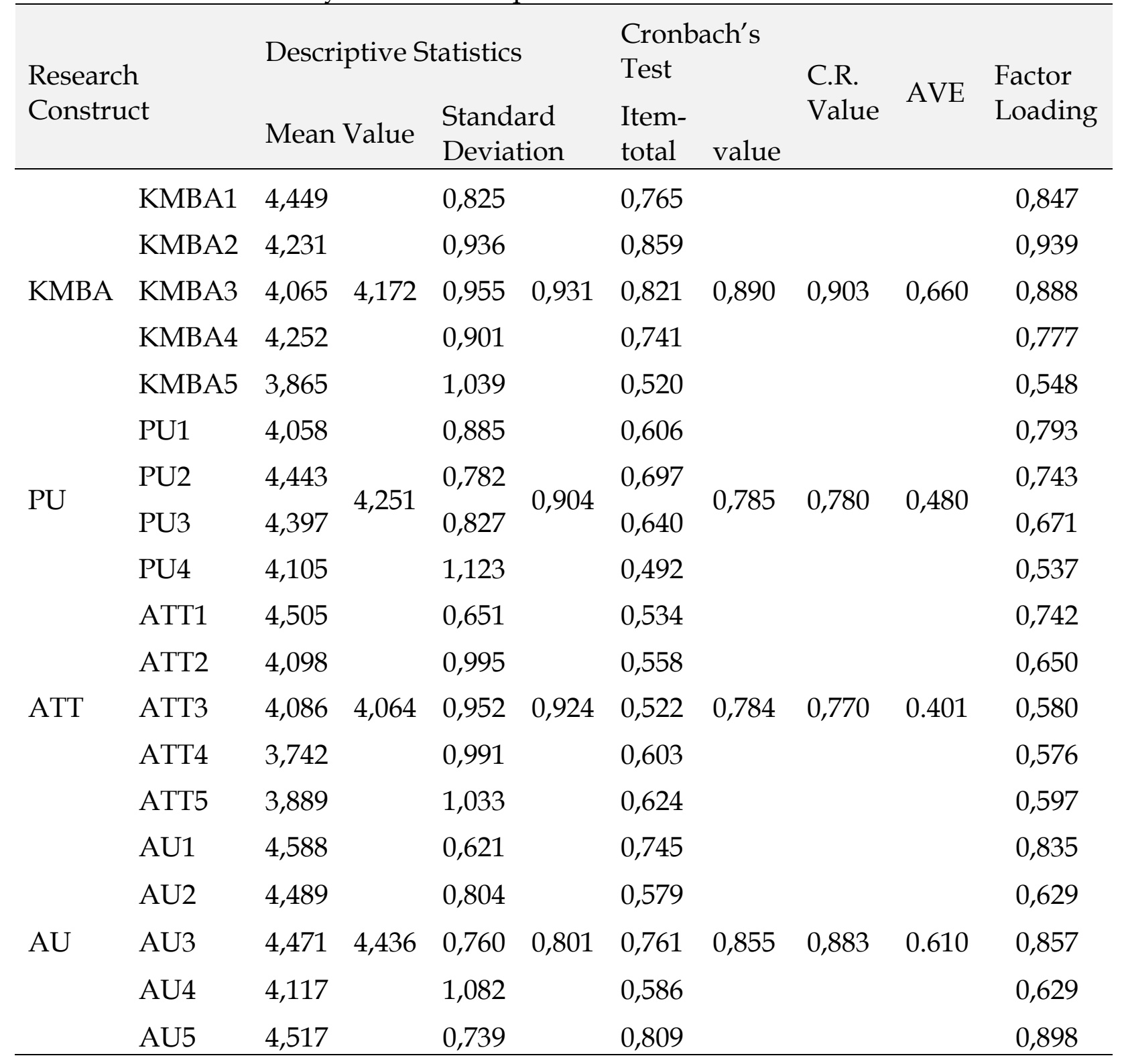

Key: Knowledge of mobile banking applications (KMBA), perceived usefulness of mobile banking applications (PU), Attitudes towards mobile banking applications (ATT), Actual use 
of mobile banking applications (AU), SD, standard deviation; $C R$, composite reliability; AVE, average variance extracted.

According to Nunnally and Bernstein (1994) the reliability of a measure is supported if Cronbach's alpha is 0.7 or higher. The results provided in Table 2 show that the Cronbach's alpha values for each research variable were as follows: KMBA = $0.890, \mathrm{PU}=0.904, \mathrm{ATT}=0.924$ and $\mathrm{AU}=0.801$. Cronbach's alpha scores indicate that each construct exhibits strong internal reliability (Lee 2009). Because the Cronbach's alpha values of the constructs exceeded the recommended 0.70 , this shows that all the variables were reasonably reliable.

Table 2 shows the loading of each item on their construct. The lowest value for each respective item loading for the research constructs is 0.537; all the individual item loadings exceed the recommended value of 0.5 (Anderson \& Gerbing, 1988). This indicates that all the measurement instruments are acceptable and reliable because all the individual items converged well. More than $50 \%$ of each item's variance was shared with its respective construct (Fraering \& Minor, 2006). Composite reliability (CR) and average variance extracted (AVE) for each construct were also computed and assessed to determine if they met the required thresholds of reliability and validity. As per the results shown in Table 2 , the lowest CR value 0.780 is well above the recommended value of 0.6 (Hulland, 1999) , while the lowest obtained AVE value 0.401 is above the recommended value of 0.4 (Anderson \& Gerbing, 1988). This indicates that convergent validity was achieved, further confirming the measurement instruments' excellent internal consistency and reliability. By and large, these results provided evidence for acceptable levels of research scale reliability (Chinomona \& Chinomona, 2013).

According to Field (2013), discriminant validity refers to items measuring different concepts. Table 2 shows the results of the discriminant validity analysis. As shown in Table 3, all the correlation coefficients of this study fell below 0.70 , thereby confirming the theoretical uniqueness of each variable in this research (Field, 2013).

Table 3. Correlation Matrix

\begin{tabular}{lllll}
\hline VARIABLES & KMBA & PU & ATT & AU \\
\hline KMBA & 1 & - & - & - \\
PU & $0.637^{* *}$ & 1 & - & - \\
ATT & $0.556^{* *}$ & $0.569^{* *}$ & 1 & - \\
AU & $0.595^{* *}$ & $0.600^{* *}$ & $0.472^{* *}$ & 1 \\
\hline
\end{tabular}

Key: Knowledge of mobile banking applications (KMBA), perceived usefulness of mobile banking applications (PU), Attitudes towards mobile banking applications (ATT), Actual use of mobile banking applications (AU).

\section{Structural Equation Modelling}




\section{Measurement model evaluation}

A confirmatory model development strategy was followed to confirm the dimensional structure of the constructs used in this research as well as the level of internal consistency among the respective indicators. Precisely, a measurement model was specified using maximum likelihood extrapolation (MLE) technique. Initial model estimation was extrapolated at $\mathrm{CMIN} / \mathrm{DF}=1.814(<3.0) ; p<0.01$. It is imperative to note that researchers disregard the significant $\chi^{2}$ value because of sensitivity of the index to large sample sizes and many indicators (Malhotra 2010). To overcome this limitation, Byrne (2010) proffers that a more 'pragmatic approach is to report on multiple indices that are not based on the central distribution'. Therefore, the following indices demonstrated adequate model fit as follows: CMIN/DF=1.814, CFI=0.969, $\mathrm{GFI}=0.921, \mathrm{IFI}=0.969, \mathrm{RFI}=0.933, \mathrm{NFI}=0.933, \mathrm{TLI}=0.962$ and $\mathrm{RMSEA}=0.050$.

\section{Structural Model Assessment and Hypothesis Testing}

Results of the structural model analysis indicated that all the structural model fit statistics were within the tolerable ranges: $\chi^{2} / \mathrm{df}=1.811$; CFI $=0.917$, IFI $=0.927$; TLI = 0.917; RMSEA $=0.053$. A good fit is normally deemed to exist when NFI, GFI and CFI were all greater than 0.9 (Chang \& Chen, 2009). Moreover, Figure 3 depicts a structure model. A structural model examination aims to evaluate strength and direction of relationships among constructs in a model (Lee, 2009). Table 5 provides results from the structural equation modelling (SEM) analysis.

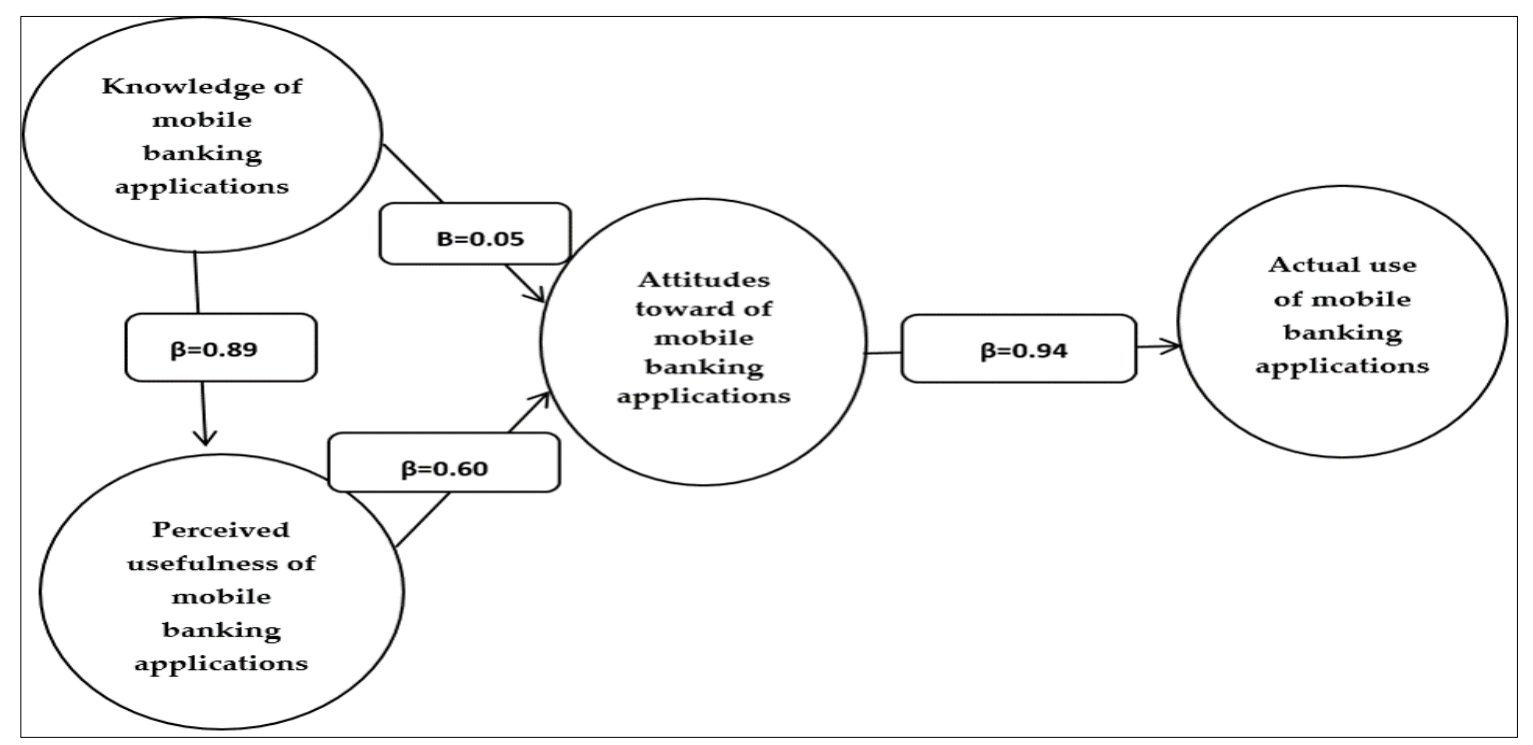

Figure 4. The Final Structural Model of the Study

Table 4: Summary of the Hypotheses Testing

\begin{tabular}{llcll}
\hline Relationships & Hypothesis & Path coefficient & $\boldsymbol{p}$ & Remarks \\
\hline PU $\leftarrow$ KMBA & H1 & 0.89 & $* * *$ & Supported \\
ATT $\leftarrow$ KMBA & H2 & 0.05 & $* * *$ & Supported
\end{tabular}




\begin{tabular}{lllll} 
ATT $\leftarrow$ PU & H3 & 0.60 & $* * *$ & Supported \\
AU $\leftarrow$ ATT & H4 & 0.94 & $* * *$ & Supported \\
\hline
\end{tabular}

Key: Knowledge of mobile banking applications (KMBA), perceived usefulness of mobile banking applications (PU), Attitudes towards mobile banking applications (ATT), Actual use of mobile banking applications (AU)

***, significance level $p<0.01$.

\section{Discuss of Results of Hypothesis Testing}

It is observed that all the proposed relationships were found to be both supported and significant. The first hypothesis, H1, knowledge of mobile banking applications and perceived usefulness of mobile banking applications. This relationship was both supported and significant at $p<0.01$ with a path coefficient of 0.89 . It was the second strongest relationship of the conceptualised model. The finding from this hypothesis suggested that the more consumers knew about mobile banking applications the more they perceived it to be useful.

The second hypothesis, $\mathrm{H} 2$, knowledge of mobile banking applications and attitude towards mobile banking applications. It was found that knowledge of mobile banking applications directly and positively influences attitudes of mobile banking applications. This relationship was both supported and significant at $p<0.01$ with a path coefficient of 0.05 . It however be noted that this was the weakest of all relationships. This possibly suggested that as much as consumer attitude towards mobile banking applications was influenced by their knowledge of mobile banking applications, that knowledge alone was not enough to definitively influence consumer attitudes.

Possibly they were other factors that would help determine consumer attitudes towards mobile banking applications in addition to knowledge of it. The third hypothesis, H3, perceived usefulness of mobile banking applications and attitudes toward mobile banking applications. This relationship was both supported and significant at $p<0.01$ with a path coefficient of 0.60 . This relationship was also found to be the third strongest relationship. This outcome proposes that perceived usefulness of mobile banking application stimulates attitudes towards the use of mobile banking applications. In other words, this finding suggested that the more consumers perceived mobile banking applications to be useful the more they would be more positive their attitudes would become toward using mobile banking applications. Along these lines, this examination fails to dismiss H3. This finding is in line with Dixit and Prakash (2018) who stated that attitudes towards the use of a social networking site were indeed directly and positively impacted by both the perceived usefulness of using that site. The results obtained in this study are also in line with the findings of Van De Bogart and Wichadee (2015) who found that students' PU of LINE positively influenced their attitude towards usage. 
The last hypothesis, H4, attitude towards mobile banking applications and actual use of mobile banking applications. This relationship, like all the other relationships, was both supported and significant at $\mathrm{p}<0.01$ with an estimated coefficient of 0.94 . It is also important to note that it was the strongest of all relationships. This finding suggested that the more the positive the consumer attitudes are, the higher the likelihood of them to adopt mobile banking applications.

\section{Implications of the Study}

The findings of this study gave rise to numerous implications. First, according to (H1) this study confirmed that knowledge of mobile banking applications indeed positively and directly impacted Generation Z student consumers' attitudes toward the use of mobile banking applications. This implies that banks in South Africa should consider provided more and more education on banking to their existing and potential Generation $\mathrm{Z}$ student customers to convince them to adopt mobile banking services and better communicate the benefits of using such services. The study also confirmed that attitude towards mobile banking applications and actual use of mobile banking applications were the strongest relationship (H4). This then implied that banks should ensure that Generation $\mathrm{Z}$ student consumer attitudes are constantly monitored through customer surveys and other data collection tools and they significantly impacted consumers' actual use of mobile banking applications. Another essential implication that emerged from the research according to $(\mathrm{H} 2)$ was that banks had to ensure that as much knowledge of mobile banking applications was provided to Generation $\mathrm{Z}$ student consumer for them to perceive mobile banking as being useful in today's post-modern era. According to (H3), perceived usefulness of mobile banking applications directly led to positive attitude towards mobile banking applications. This implied that mobile banking applications had to be user-friendly to customers in order for them to be portrayed positively by the targeted mobile banking customers.

It is also imperative to note that, the findings of this study potentially help banking executives and bank managers to recognise and tailor those mobile banking customers' needs. The findings of this study opened numerous avenues to improve customer mobile banking experiences in South Africa and other developing countries. Additionally, on the management of mobile banking, bank managers can understand how the Generation $\mathrm{Z}$ cohort perceive mobile banking and they can enhance mobile banking applications to improve customer service experience. These findings are the strategic avenues to customise the set of services based on customer profiles within a developing country context.

\section{Conclusion}

The study established that attitudes toward the use of mobile banking applications and their actual use were the most important consideration to customers. As other insightful results can be obtained, it is also vital to test the model with other 
generational cohorts like the Generation Y, Generation X and Baby Boomers, which are less likely to be as techno-savvy as the Generation Z. The weakest relationship was that of knowledge of mobile banking applications on attitudes towards mobile banking applications. This therefore suggested that attitudes of customers were not influenced much by their knowledge of mobile banking applications.

\section{Limitations}

Despite this study's interesting results, its constraints are worthy of notice. Firstly, the findings are not generalisable to non-student samples because students constituted the sample for gathering data. The future study, therefore, requires considering non-students to generalise the outcomes. In addition, the present research was restricted to the province of Gauteng in South Africa, with the other provinces being excluded. This research should be replicated in other South African provinces and other developing countries for comparative outcomes.

In conclusion, the quantitative nature of the examination may have produced more illuminating and extravagant information, if a qualitative methodology was considered in this investigation. Future studies may, as necessary, explore indistinguishable points from the current examination using a blended process technique to improve the expansiveness of the examination outcomes. In addition, this study also looked at the relationship between knowledge of mobile banking applications and the actual use of mobile banking applications.

\section{Recommendations and Further Research}

Theoretically potential hypotheses left out in this research could be tested. For example, it would therefore be recommended for further research to investigate a direct relationship between perceived usefulness and actual usefulness of mobile banking applications. It would therefore be recommended that more diversity be provided in further research. The relationship knowledge of mobile banking applications and actual use of mobile banking applications could also be tested. Testing this relationship could reveal possibly more accurate results of the extent to which the knowledge of mobile banking applications impacted the actual use of mobile banking applications. Additional constructs could be added to the present conceptual model as this would potentially reveal additional insights into how Generation Z student consumers within a South African context have accepted mobile banking applications.

\section{References}

Abbott, D. (2015). SA ripe for a mobile banking revolution, viewed, Retrieved from http://www.fin24.com/Tech/Opinion/SA-ripe-for-a-mobile-bankingrevolution-20150223 Accessed 05/05/2021

Afshan, S., \& Sharif, A. (2016). Acceptance of mobile banking framework in Pakistan. Telematics and Informatics, 33(2), 370-387. 
Ajzen, I. (1985). From intentions to actions: A theory of planned behavior. In Action control (pp. 11-39). Springer.

Ajzen, I. (1991). The theory of planned behavior. Organisational Behavior and Human Decision Processes, 50(2), 179-211.

Alafeef, M., Singh, D., \& Ahmad, K. (2011). Influence of demographic factors on the adoption level of mobile banking applications in Jordan. Research Journal of Applied Sciences, 6(6), 373-377.

Anderson, J.C. \& Gerbing, D.W. (1988), 'Structural equation modeling in practice: A review and recommended two-step approach', Psychological Bulletin 103(3), 411-423.

Audi, M. F. (2015). Adoption of mobile banking applications in Lebanon. The Journal of Internet Banking and Commerce, 21(1), 1-12.

Baabdullah, A. M., Alalwan, A. A., Rana, N. P., Kizgin, H., \& Patil, P. (2019). Consumer use of mobile banking (M-Banking) in Saudi Arabia: Towards an integrated model. International Journal of Information Management, 44, 38-52.

Balabanoff, G. A. (2014). Mobile banking applications: consumer behaviour, acceptance and adoption strategies in Johannesburg, South Africa (RSA). Mediterranean journal of social sciences, 5(27 P1), 247-247.

Bals, C., Smolnik, S., \& Riempp, G. (2007). Assessing user acceptance of a knowledge management system in a global bank: Process analysis and concept development. In 2007 40th Annual Hawaii International Conference on System Sciences (HICSS'07) (pp. 203c-203c). IEEE.

Basar, O. E., Alptekin, G., Volaka, H. C., Isbilen, M., \& Incel, O. D. (2019). Resource usage analysis of a mobile banking application using sensor-and-touchscreenbased continuous authentication. Procedia Computer Science, 155, 185-192.

Bassiouni, D. H., \& Hackley, C. (2014). 'Generation Z'children's adaptation to digital consumer culture: A critical literature review. Journal of Customer Behaviour, 13(2), 113-133.

Bernstein, R. (2015). Move over millennials - here comes gen Z. Ad age. Retrieved Fromhttp://adage.com/article/cmo-strategy/move-millennialsgenz/296577. Accessed 05/05/2021

Borowski-Beszta, M., \& Kiermas, A. (2019). The Usage of mobile banking applications in Poland: Empirical results. Copernican Journal of Finance $\mathcal{E}$ Accounting, 8(1), 925.

Byrne, B.M. (2010). Structural equation modelling with AMOS: Basic concepts, applications and programming. 2nd ed, New York, NY: Routledge.

Chang, H. H., \& Chen, S. W. (2009). Consumer perception of interface quality, security, and loyalty in electronic commerce. Information \& management, 46(7), 411-417.

Chigada, J. M., \& Hirschfelder, B. (2017). Mobile banking in South Africa: A review and directions for future research. South African Journal of Information Management, 19(1), 1-9. https://doi.org/10.4102/sajim.v19i1.789

Chinomona, R., \& Chinomona, E. (2013). The influence of employees' perceptions of organisational politics on turnover intentions in Zimbabwe's SME sector. South African Journal of Business Management, 44(2), 57-66. 
Coetzee, J. (2018). Strategic implications of Fintech on South African retail banks. South African Journal of Economic and Management Sciences, 21(1), 1-11.

Columinate, 2015, Columinate 2015 internet banking Satisfaction survey shows improvement from local banks, viewed 1 May 2021, Retrieved from http:/ / www.bizcommunity.com/Article/196/19/128105.html

Accessed 05/05/2021

Davis, F. D. (1993). User acceptance of information technology: system characteristics, user perceptions and behavioral impacts. International journal of man-machine studies, 38(3), 475-487.

Dixit, R.V. \& Prakash, G. (2018). Intentions to use social networking sites (SNS) using technology acceptance model (TAM) an empirical study. Paradigm, 22(1), 6579.

Duffett, R. G. (2017). Influence of social media marketing communications on young consumers' attitudes. Young Consumers, 18(1), 19-39.

Eriksson, K., Kerem, K., \& Nilsson, D. (2005). Customer acceptance of internet banking in Estonia. International journal of bank marketing, 23(2), 200-216.

Field, A., (2013), Discovering statistics using IBM SPSS, 4th edn., Sage, London

Fishbein, M. \& Ajzen, I., (1975), Belief, attitude, intention and behaviour: An introduction to theory and research, Addison-Wesley, Reading, MA.

Fishbein, M., \& Ajzen, I. (1977). Belief, attitude, intention, and behavior: An introduction to theory and research.

Fister-Gale, S. (2015). Forget Millennials: are you ready for Generation Z. Chief Learning Officer, 14(7), 38-48.

Fraering, M., \& Minor, M. S. (2006). Sense of community: An exploratory study of US consumers of financial services. International Journal of Bank Marketing, 24(5), 284-306.

Govender, I., \& Sihlali, W. (2014). A study of mobile banking adoption among university students using an extended TAM. Mediterranean Journal of Social Sciences, 5(7), 451-459.

Gu, J. C., Lee, S. C., \& Suh, Y. H. (2009). Determinants of behavioral intention to mobile banking. Expert Systems with Applications, 36(9), 11605-11616.

Hulland, J. (1999). Use of partial least squares (PLS) in strategic management research: A review of four recent studies. Strategic management journal, 20(2), 195-204.

Hung, S.-Y., Ku, C.-Y., \& Chang, C.-M. (2003). Critical factors of WAP services adoption: An empirical study. Electronic Commerce Research and Applications, 2(1), 42-60.

Hwang, H.S., 2017, 'The Influence of personality traits on the Facebook addiction', KSII Transactions on Internet $\mathcal{E}$ Information Systems 11(2), 1032-1042.

Karsh, A. (2020). Fintech in the eyes of Millennials and Generation Z (the financial behavior and Fintech perception). Banks and Bank Systems, 15(3), 20-28.

Khan, M. Z. A., \& Khan, S. (2012). Internet versus mobile banking: A study of Peshawar city (Pakistan). The Journal of Internet Banking and Commerce, 17(3), 1-13. 
Khrais, L.T., 2015, 'Highlighting the vulnerabilities of online banking system', Journal of Internet Banking $\mathcal{E}$ Commerce 20(3), n.p. https://doi.org/10.4172/12045357.1000120

Koenaite, M., Chuchu, T., \& Venter de Villiers, M. (2019). The impact of mobile banking on the adoption of banking products and services in South Africa, using the technology acceptance model. Journal of Business and Retail Management Research, 13(3), 93-103.

Lee, M. C. (2009). Predicting and explaining the adoption of online trading: An empirical study in Taiwan. Decision Support Systems, 47(2), 133-142.

Leonard, L.N.K., Clonah, T.P. \& Kreie, J. (2004). What influences information technology, ethical behavioral intention, planned behavior, reasoned action, perceived importance, or individual Characteristics'? Information and Management, 42, 143- 15

Lin, H.F. (2011). An empirical investigation of mobile banking adoption: The effect of innovation attributes and knowledge-based trust. International journal of information management, 31(3), 252-260.

Luo, X., Li, H., Zhang, J., \& Shim, J. P. (2010). Examining multi-dimensional trust and multi-faceted risk in initial acceptance of emerging technologies: An empirical study of mobile banking services. Decision support systems, 49(2), 222-234.

Maduku, D. K. (2014). Behavioral intention towards mobile banking usage by South African retail banking clients. Investment management and financial innovations, 11(3), 37-51.

Mashele, F., \& Chuchu, T. (2018). An Empirical Investigation into the Relationship between Sustainability and Supply Chain Compliance within the South African public and the private sector. Journal of Business $\mathcal{E}$ Retail Management Research. 12(2), 121-132

Masinge, K. (2011). Factors influencing the adoption of mobile banking services at the Bottom of the Pyramid in South Africa (Doctoral dissertation, University of Pretoria).

Matikiti, R., Mpinganjira, M., \& Roberts-Lombard, M. (2018). Application of the technology acceptance model and the technology-organisation-environment model to examine social media marketing use in the South African tourism industry. South African Journal of Information Management, 20(1), 1-12.

Maynard, N. (2020). Digital Banking: Banking-as-a-Service, Open Banking \& Digital Transformation 2020-2024. Juniper Research. Retrieved from:

https:/ / www.juniperresearch.com/researchstore/fintech-payments/digitalbanking-trends-report Accessed 01/11/2020.

Mgxaji, B., Chinomona, R., \& Chuchu, T. (2016). The Predictors of Business Performance in the Investment Management Industry. Journal of Global Business \& Technology, 12(2), 56-69

Mohammadi, H. (2015). Investigating users' perspectives on e-learning: An integration of TAM and IS success model. Computers in human behavior, 45, 359-374. 
Morgan, J. (2016). Generation $\mathrm{Z}$ and the 6 forces shaping the future of business. Retrieved from https://www.inc.com/jacob-morgan/generation-z-and-the6-forces-shaping-the-future-of-business.html. Accessed 05/05/2021

Moser, F. (2015). Mobile banking: A fashionable concept or a sinstitutionalised channel in future retail banking? Analysing patterns in the practical and academic mobile literature. International Journal of Banking Marketing, 33, 167-177.

Munoz-Leiva, F., Climent-Climent, S., \& Liébana-Cabanillas, F. (2017). Determinants of intention to use the mobile banking apps: An extension of the classic TAM model. Spanish Journal of Marketing-ESIC, 21(1), 25-38.

Nel, J., Raleting, T., \& Boshoff, C. (2012). Exploiting the technology cluster effect to enhance the adoption of WIG mobile banking among low-income earners. Management Dynamics: Journal of the Southern African Institute for Management Scientists, 21(1), 30-44.

Nguyen, D. (2015). Understanding perceived enjoyment and continuance intention in mobile games. Master's thesis, Department of Information and Service Economy, Aalto University. School of Business.

Nicoletti, B. (2014). Mobile banking. In Mobile Banking (pp. 19-79). Palgrave Macmillan.

Nunnally, J. C., \& Bernstein, I. H. (1994). Psychological theory. New York, NY: MacGraw-Hill, 131-147.

Priporas, C.V., Stylos, N., \& Fotiadis, A. K. (2017). Generation Z consumers' expectations of interactions in smart retailing: A future agenda. Computers in Human Behavior, 77, 374-381.

Purnawirawan, N., De Pelsmacker, P., \& Dens, N. (2012). Balance and sequence in online reviews: How perceived usefulness affects attitudes and intentions. Journal of interactive marketing, 26(4), 244-255.

Raosoft Inc. (2004). Sample size calculator, viewed 27 October 2018, from http://www.raosoft.com/samplesize.htm

Ratten, V. (2011). Mobile banking innovations and entrepreneurial adoption decisions. International Journal of E-Entrepreneurship and Innovation (IJEEI), 2(2), 27-38.

Rehman, Z. U., \& Shaikh, F. A. (2020). Critical factors influencing the behavioral intention of consumers towards mobile banking in Malaysia. Engineering, Technology E Applied Science Research, 10(1), 5265-5269.

Rose, J., \& Fogarty, G. J. (2006). Determinants of perceived usefulness and perceived ease of use in the technology acceptance model: senior consumers' adoption of self-service banking technologies. In Proceedings of the 2nd Biennial Conference of the Academy of World Business, Marketing and Management Development: Business Across Borders in the 21st Century. 2, 122-129

Sachdev, S. (2019). Welcome the New Kids on the Block: How Millennials and Gen Z AreDisrupting Fintech. Martechseries. Retrieved from https://martechseries.com/mts-insights/guest-authors/welcome-the-newkids-on-the-block-how-millennials-and-genzare-disrupting-fintech/

Seemiller, C., \& Grace, M. (2016). Generation Z goes to college. John Wiley \& Sons. 
Shaikh, A. A., Glavee-Geo, R., \& Karjaluoto, H. (2015). An empirical investigation of mobile banking services adoption in Pakistan. International Journal of Economics and Management Engineering, 9(11), 3609-3617.

Shambare, R. (2011). Cell phone banking adoption in South Africa. Business and Economic Research, 1(1), 1-15.

Shankar, A., \& Kumari, P. (2016). Factors affecting mobile banking adoption behavior in India. The Journal of Internet Banking and Commerce, 21(1).

Shankar, A., Jebarajakirthy, C., \& Ashaduzzaman, M. (2020). How do electronic word of mouth practices contribute to mobile banking adoption? Journal of Retailing and Consumer Services, 52, 101920.

Strauss, W., \& Howe, N. (1991). Generations: The history of America's future, 15842069. New York: William Morrow.

Thusi, P., \& Maduku, D. K. (2020). South African millennials' acceptance and use of retail mobile banking apps: An integrated perspective. Computers in Human Behavior, 111, 106405.

Vahrenkamp, A. (2017). Generation Z: The Kids Are All Right - How High Schoolers

Perceive Financial Needs and Opportunities. Retrieved from https://www.raddon.com/GenZ Accessed 05/05/2021

Van De Bogart, W. \& Wichadee, S., 2015, 'Exploring students' intention to use LINE for academic purposes based on technology acceptance model', The International Review of Research in Open and Distributed Learning 16(3), 65-85

Van den Bergh, J., \& Behrer, M. (2016). How cool brands stay hot: Branding to Generations $Y$ and Z. Kogan Page Publishers.

Van Deventer, M., De Klerk, N., \& Bevan-Dye, A. (2017). Influence of perceived integrity and perceived system quality on Generation Y students' perceived trust in mobile banking in South Africa. Banks and Bank Systems, 12(1-1), 128134.

Vedadi, A., \& Warkentin, M. (2016). Continuance intention on using mobile banking applications: A replication study of information systems continuance model. AIS Transactions on Replication Research, 2(1), 1-11.

Venkatesh, V., Morris, M. G., Davis, G. B., \& Davis, F. D. (2003). User acceptance of information technology: Toward a unified view. MIS Quarterly, 425-478.

Virgillito, G., Personal Communication (2013, 2 July 2013). [Head of Banking Apps]

Wang, Y., Wang, S., Wang, J., Wei, J., \& Wang, C. (2020). An empirical study of consumers' intention to use ride-sharing services: using an extended technology acceptance model. Transportation, 47(1), 397-415.

Weideman, A. (2014). Innovation and reciprocity in applied linguistics. Literator: Journal of Literary Criticism, Comparative Linguistics and Literary Studies, 35(1), 110.

White, A (2021). Millennials and Gen Z are the most likely to use mobile banking apps-here's why, plus budgeting tips. Available online on: https:// www.cnbc.com/select/why-millennials-gen-z-use-mobile-bankingapps / Assessed date 1/5/2021 
Wood, S. (2013). Generation Z as consumers: trends and innovation. Institute for Emerging Issues: NC State University, 1-3.

Wu, H. Y., Lin, C. C., Li, O., \& Lin, H. H. (2010). A study of bank customers' perceived usefulness of adopting online banking. Global journal of business research, 4(3), 101-108.

Yen, Y. \& Wu, F. (2016). Predicting the adoption of mobile financial services: The impacts of perceived mobility and personal habit. Computers in Human Behaviour, (65), 31-42. 